\title{
KAT7 wt Allele
}

National Cancer Institute

\section{Source}

National Cancer Institute. KAT7 wt Allele. NCI Thesaurus. Code C73661.

Human KAT 7 wt allele is located in the vicinity of $17 q 21.32$ and is approximately $40 \mathrm{~kb}$ in length. This allele, which encodes histone acetyltransferase KAT7 protein, may play a role in activation and repression of RNA polymerase II transcription. 